B O N N E V I L L E Monitoring and Evaluation

Statistical Support for Life-cycle Studies

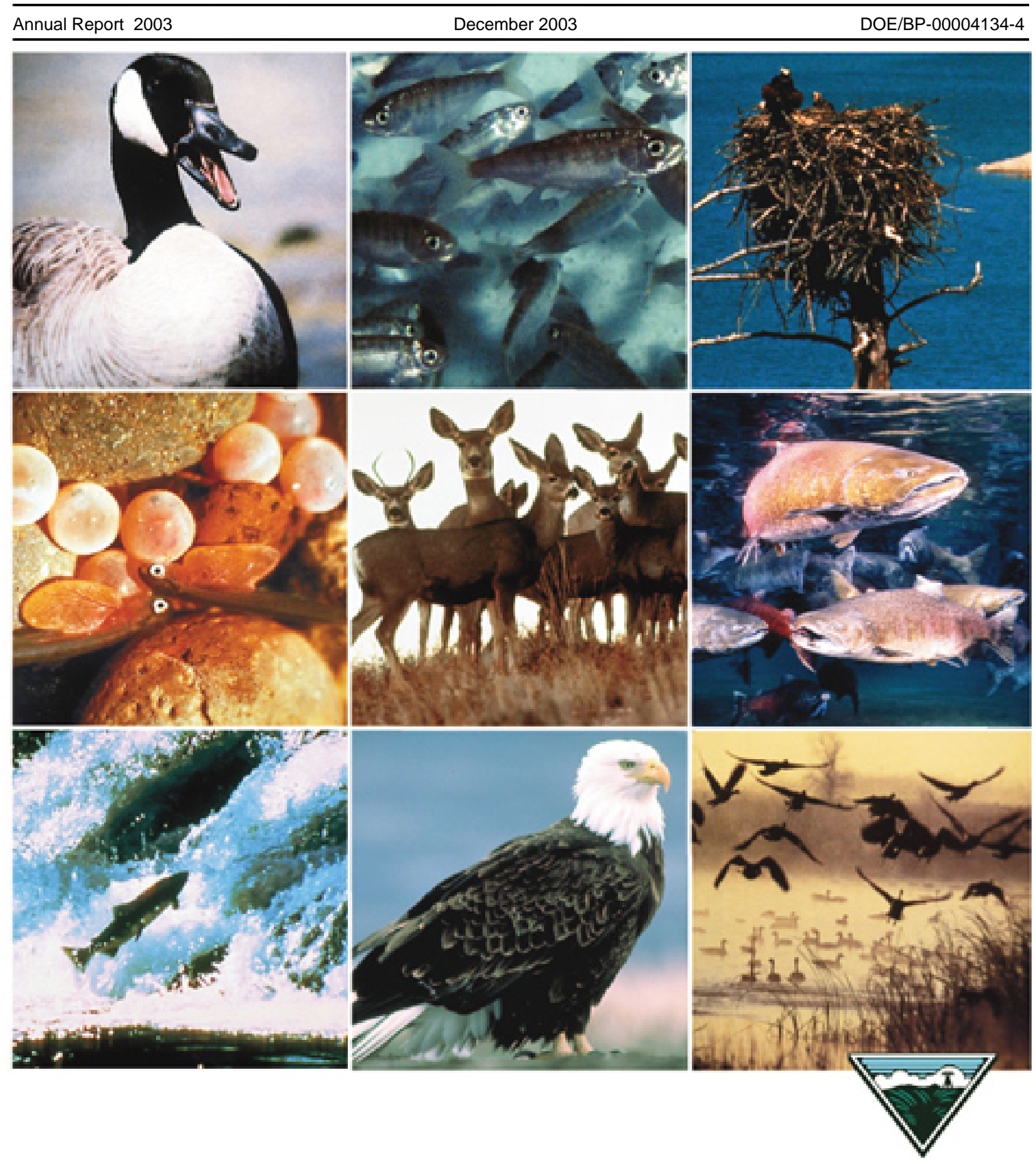


This Document should be cited as follows:

Skalski, John, "Monitoring and Evaluation; Statistical Support for Life-cycle Studies", 2003

Annual Report, Project No. 199105100, 22 electronic pages, (BPA Report DOE/BP-00004134-4)

\author{
Bonneville Power Administration \\ P.O. Box 3621 \\ Portland, OR 97208
}

This report was funded by the Bonneville Power Administration (BPA), U.S. Department of Energy, as part of BPA's program to protect, mitigate, and enhance fish and wildlife affected by the development and operation of hydroelectric facilities on the Columbia River and its tributaries. The views in this report are the author's and do not necessarily represent the views of BPA. 


\title{
2003 Annual Report
}

\section{Monitoring and Evaluation: Statistical Support for Life-Cycle Studies}

Contract No. 00004134

Project No. 199105100

\author{
Prepared for: \\ Bonneville Power Administration \\ P.O. Box 3621 \\ 905 NE 11th Avenue \\ Portland, Oregon 97232
}

\author{
Prepared by: \\ John R. Skalski \\ Columbia Basin Research \\ School of Aquatic and Fishery Sciences \\ University of Washington \\ 1325 Fourth Avenue, Suite 1820 \\ Seattle, Washington 98101-2509
}

9 December 2003 


\section{Executive Summary}

This report summarizes the statistical analysis and consulting activities performed under Contract No. 00004134, Project No. 199105100 funded by Bonneville Power Administration during 2003. These efforts are focused on providing real-time predictions of outmigration timing, assessment of life-history performance measures, evaluation of status and trends in recovery, and guidance on the design and analysis of Columbia Basin fish and wildlife studies monitoring and evaluation studies.

\section{Mission Statement}

The overall objective of the project is to provide BPA and the rest of the fisheries community with statistical guidance on design, analysis, and interpretation of monitoring data, which will lead to improved monitoring and evaluation of salmonid mitigation programs in the Columbia/Snake River Basin. This overall goal is being accomplished by making fisheries data readily available for public scrutiny, providing statistical guidance on the design and analyses of studies by hands-on support and written documents, and providing real-time analyses of tagging results during the smolt outmigration for review by decision makers. For a decade, this project has been providing in-season projections of smolt outmigration timing to assist in spill management. As many as 50 different fish stocks at 8 different hydroprojects are tracked and real-time to predict the "percent of run to date" and "date to specific percentile."

The project also conducts added-value analyses of historical tagging data to understand relationships between fish responses, environmental factors, and anthropogenic effects. The statistical analysis of historical tagging data crosses agency lines in order to assimilate information on salmon population dynamics irrespective of origin. The lessons learned from past studies are used to improve the design and analyses of future monitoring and evaluation efforts.

Through these efforts, the project attempts to provide the fisheries community with reliable analyses and interpretations of monitoring data to evaluate hydrosystem operations and the recovery of endangered and threatened salmonid stocks. 


\section{Table of Contents}

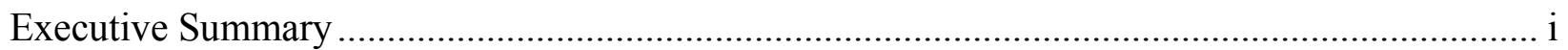

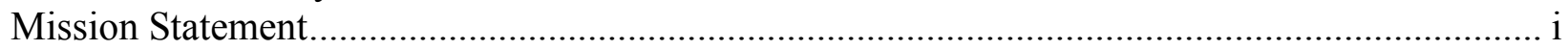

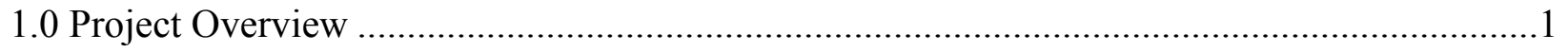

2.0 Overview of Annual Accomplishments: 1 January - 31 December 2003 ...........................2

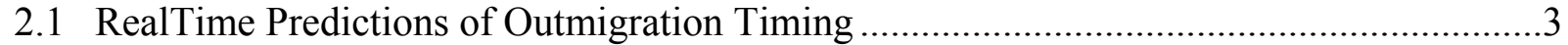

2.2 Post-Season Outmigration Success ...........................................................................5

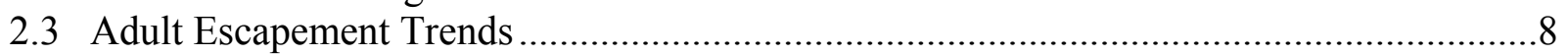

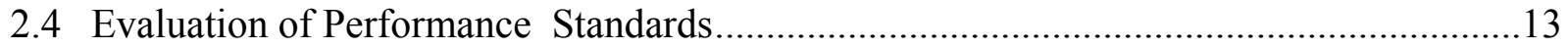

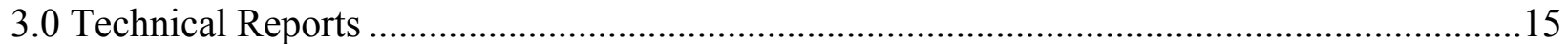

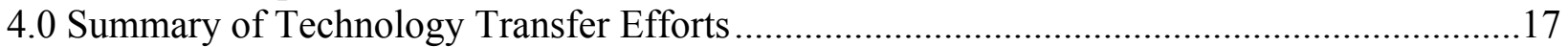




\subsection{Project Overview}

This project was initiated in 1991 in response to the Endangered Species Act (ESA) and the subsequent 1994 Council Fish and Wildlife Program (FWP) call for regional analytical methods for monitoring and evaluation. This project supports the need to have the "best available" scientific information accessible to the BPA, fisheries community, decision-makers, and public by analyzing historical tagging data to investigate smolt outmigration dynamics, salmonid life histories and productivity, and providing real-time analysis to monitor outmigration timing for use in water management and fish operations of the hydrosystem. To support realtime monitoring and provide information dissemination, the project provides real-time analyses of PIT-tag data and smolt passage indices to predict outmigration timing at 8 Snake and Columbia River dam sites. This information is coupled with travel time information and barging predictions in the Snake River Basin. Daily updates are provided for yearling and subyearling chinook, steelhead, and sockeye from April through September of each year since 1994. These predictions, along with supporting information, can be retrieved and independently analyzed using interactive software and graphs on the internet (http://www.cbr.washington.edu/rt/rt.html). The second element this project provides is value-added analyses of historical tagging data by testing hypotheses, estimating parameters, and investigating interrelationships without the tremendous costs of additional field studies. The third element of this project is to provide statistical assistance to the BPA and the NW fisheries community on an as-needed bassis. These efforts are used to provide BPA with independent assessment capabilities and provide technology transfer to regional investigators.

Specific objectives of the program include the following:

1. Provide in-season real-time predictions of juvenile smolt outmigration including "percent run to date" and "date to specified percentile" for all major stocks to all major hydroprojects on the Snake/Columbia River.

2. Assist in the development of statistical and data analysis tools for reviewing, summarizing, and investigating flow, temperature, smolt and adult counts, etc., on the second-tier database DART managed by the University of Washington (UW). 
3. Interpreting the effects of flow and spill on the outmigration success for BPA reporting needs.

4. Synthesize information from historical fish tagging studies to improve understanding of migration dynamics, demographics, hydropower effects, and climatic and ocean effects on salmonid recovery.

5. Develop improved monitoring and evaluation capabilities to provide more accurate and precise information for better inriver management to optimize operational and fish passage strategies for endangered and threatened salmon populations.

In these value-added analyses of historical tagging data, this program uses coded-wire-tag (CWT), passive integrated transponder (PIT) tag, balloon-tag, and radio-tag data collected across the Columbia River Basin. The investigations have included all life stages where pertinent tagging data exist and all major fish stocks from subyearling and yearling chinook salmon, to coho, sockeye, and steelhead. Results of this effort have resulted in 20 technical and 7 peerreviewed scientific papers.

\subsection{Overview of Annual Accomplishments: 1 January - 31 December 2003}

A summary of accomplishments the last year for Project No. 199105100 include the following:

1. Real-time predictions of outmigration timing of subyearling and yearling chinook salmon, sockeye salmon, coho salmon, and steelhead trout smolts. Fifteen different stocks and locations were monitored using Fish Passage Center (FPC) passage-index counts. An additional 34 PIT-tagged stocks were also monitored, including 9 wild runat-large stocks of yearling and subyearling chinook salmon, sockeye salmon, and steelhead trout, 23 wild release/recovery stocks of yearling and subyearling chinook salmon, and 2 hatchery-reared stocks of sockeye salmon from the Salmon River drainage.

2. All historical information on smolt survivals and travel times based on PIT-tag data from 11 hatcheries and traps have been summarized and made accessible online at http://www.cbr.washington.edu/pitSurv/. The 2003 spring migration data have also been 
analyzed and posted. The 2003 summer migration data are awaiting completion of the run, with analysis planned for December 2003 - January 2004. These annual trends can be reviewed at http://www.cbr.washington.edu/pitSurv/.

3. Adult escapement data from 37 streams and rivers have been summarized and associated with NOAA Fisheries interim recovery goals. These annual trends and recovery goals are currently being installed on DART for public inspection.

4. Assisted NOAA Fisheries, US Army Corps of Engineers, and US Geological Survey in the design of regional tagging studies and the design of salmonid monitoring efforts.

\subsection{RealTime Predictions of Outmigration Timing}

Runs-at-large of passage-indexed salmon and steelhead were tracked and forecasted by Program RealTime in 2003 at Rock Island, McNary, and John Day dams. The PIT-tagged runs forecasted by Program RealTime at McNary Dam in 2003 include wild Snake River steelhead trout, Upper Columbia River steelhead trout, the combined run of steelhead, Snake River yearling chinook salmon, Snake River sockeye salmon, Snake River subyearling chinook salmon, and Upper Columbia River salmon. The wild runs tracked at Lower Granite Dam include Snake and Clearwater river steelhead trout and Snake and Clearwater river yearling chinook salmon.

The practice of releasing unmarked hatchery salmon of all Oncorhynchus species into the Snake River has continued since 1999. To provide run-timing information on wild runs-at-large since then, the RealTime forecasting project has monitored and forecasted wild, PIT-tagged subpopulations of salmon and steelhead at Lower Granite Dam, and beginning in 2001, at McNary Dam.

The list of stocks with real-time predictions of "percent-of-run-to-date" and "date-tospecified-percentiles" during the 2003 season are as follows. 
A. Tracked beginning at Lower Granite Dam:

1. PIT-tagged spring/summer chinook stocks in the Snake River. The individual stocks include the following:
a. Bear Valley Creek
b. Big Creek
c. Catherine Creek
d. West Fork Chamberlain Creek
e. Clear Creek
f. Elk Creek
g. Grand Ronde River
h. Imnaha River
i. Johnson Creek
j. Lake Creek
k. Lemhi River
1. Lolo Creek
m. Lookingglass Creek
n. Lostine River
o. Marsh Creek
p. Minam River
q. Salmon River, South Fork
r. Secesh River
s. Valley Creek

2. Snake River PIT-tagged run-at-large of wild spring/summer chinook.

3. Snake River subyearling fall chinook salmon.

4. Snake River composite of hatchery-reared sockeye salmon from
a. Redfish Lake Creek trap
b. Alturas Lake Creek trap
c. Sawtooth trap

5. Snake River run-at-large of wild sockeye salmon.

6. Snake River run-at-large of wild steelhead.

B. Tracked beginning at McNary Dam:

1. PIT-tagged run-at-large wild of Upper Columbia River fall chinook salmon.

2. PIT-tagged run-at-large of wild Snake River fall chinook salmon.

3. PIT-tagged run-at-large of wild Snake River spring/summer chinook salmon.

4. PIT-tagged run-at-large of wild Upper Columbia River steelhead.

5. PIT-tagged run-at-large of wild Snake River steelhead.

6. PIT-tagged run-at-large of wild combined Upper Columbia River and Snake River steelhead.

C. Tracked beginning at Rock Island Dam in the Mid-Columbia:

1. Fall chinook salmon

2. Spring/summer chinook salmon

3. Sockeye salmon

4. Coho salmon

5. Steelhead 
Online run-timing predictions were provided via the internet at http://www.cbr.washington.edu/crisprt/ to the fisheries community throughout each smolt outmigration. Figure 1 illustrates two types of graphical displays available for each stock in the RealTime project.

Program RealTime performance is evaluated using MADs (mean absolute differences; the average of the absolute difference between predicted and true passage percentiles over days ), calculated for the first half of the outmigration, last half, and the season-wide outmigration. The forecasting of wild, PIT-tagged, Snake River subyearling fall chinook passage at Lower Granite Dam was comparable to previous years (season-wide MAD $=8.6 \%$ ). The run of wild, PITtagged, Upper Columbia River subyearling fall chinook salmon monitored at McNary Dam was predicted very well in 2003 (season-wide MAD = 3.3\%). The run of wild, PIT-tagged, Snake River subyearling fall chinook salmon monitored at McNary Dam was also predicted very well $(\mathrm{MAD}=2.9 \%)$. The run-at-large of wild, PIT-tagged, Snake River yearling chinook salmon smolts monitored at McNary Dam was predicted extremely well in 2003 (season-wide MAD = $2.5 \%)$.

The results of Program RealTime in forecasting run-timing and passage percentiles of Fish Passage Center passage-indexed runs-at-large to Rock Island, McNary, and John Day dams were excellent in 2003. In particular, 2 of 15 stocks had season-wide MADs near 7\%, 13 of the remaining had MADS less than 4\%, 9 less than 3\%, and 5 had season-wide MADS within $2 \%$ of the true end-of-season distribution.

\subsection{Post-Season Outmigration Success}

At 11 hatcheries and smolt traps with a consistent pattern of annual PIT-tag releases, smolt survival and travel times are annually compiled and analyzed. These analyses include 21 different stocks of yearling and subyearling chinook salmon and steelhead. The specific PIT-tag stocks analyzed annually are listed below and illustrated in Figure 2. 
Figure 1. Example of two types of graphical displays available for all stocks in the RealTime project. (a) Program RealTime 2003 predictions of run-timing of subyearling fall chinook salmon smolts at McNary Dam (thick line, with 95\% confidence intervals) compared to end-of-season observed run-timing (thin line) based on FPC passageindices of combined wild and hatchery-reared fish. (b) Historical and current year runtiming characteristics.
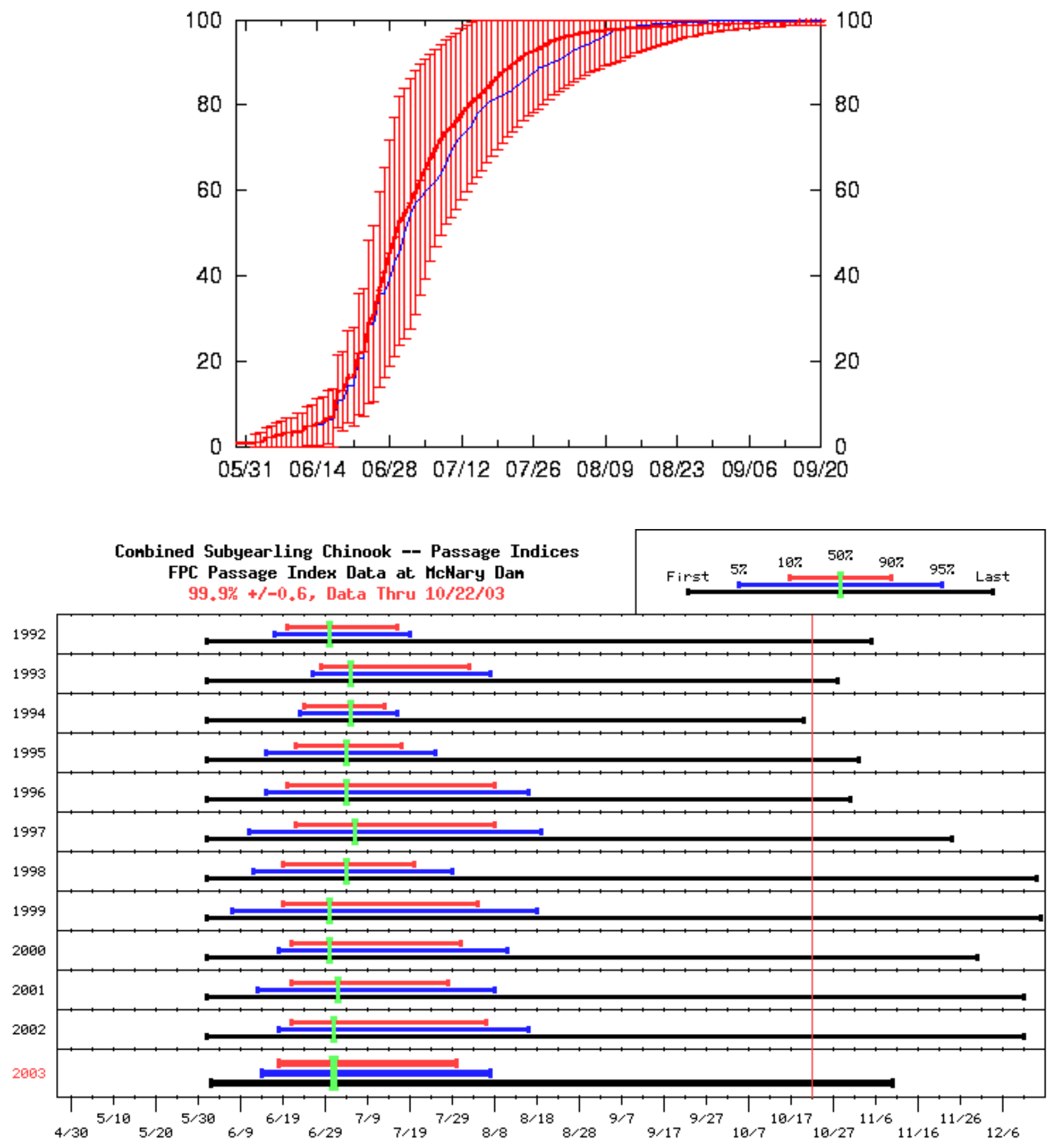
Figure 2. Map of release sites for PIT-tag survival and travel time analysis.

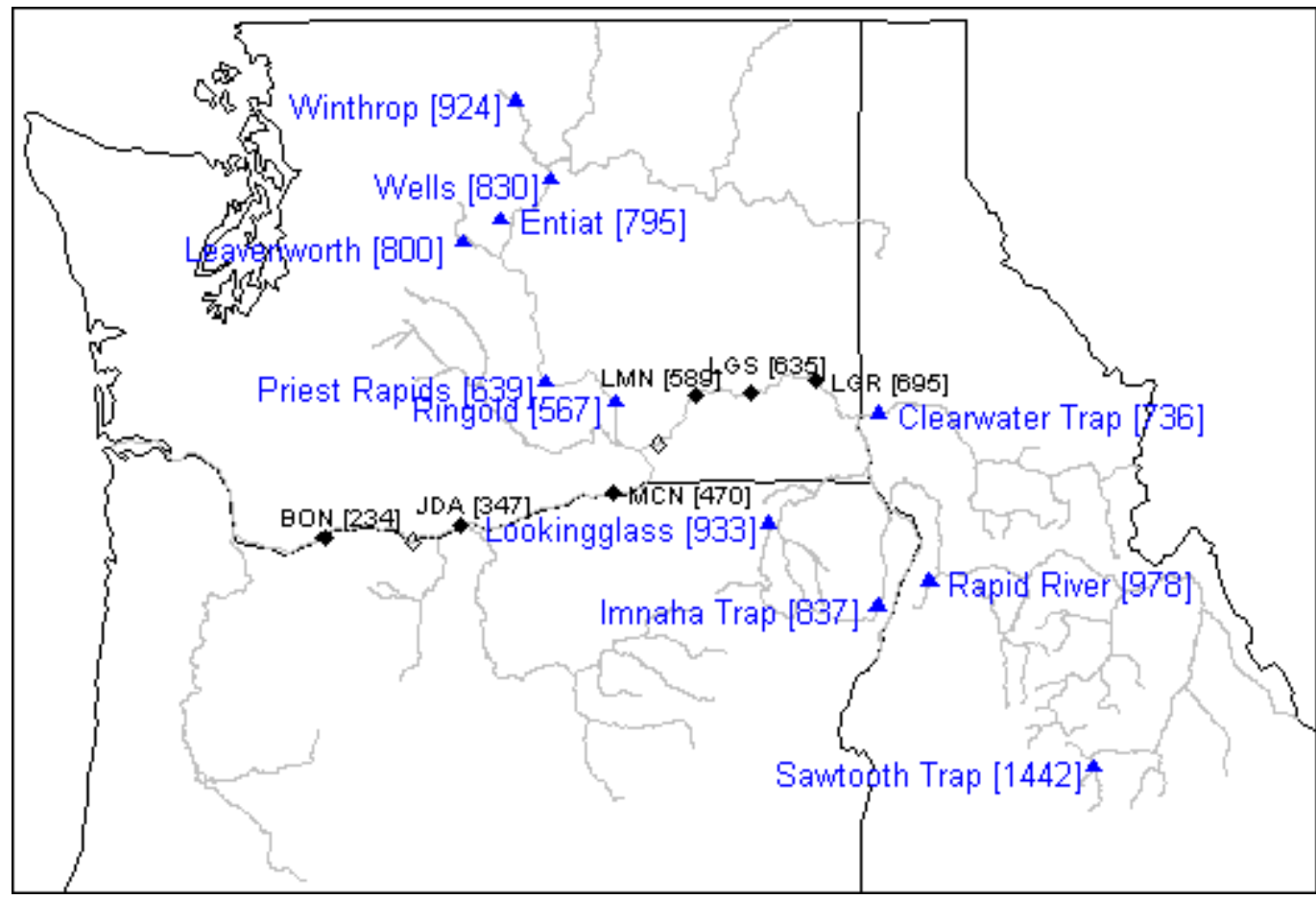

Clearwater Trap

\begin{tabular}{lcc}
\cline { 2 - 3 } \multicolumn{1}{c}{ Stock-Type } & From & To \\
\hline Spring Chinook H & 1996 & 2002 \\
Summer Chinook H & 1996 & 2002 \\
Spring Chinook H & 1995 & 2001 \\
Fall Chinook H & 1997 & 2002 \\
Fall Chinook H & 1997 & 2002 \\
Spring Chinook H & 1995 & 1999 \\
Spring Chinook H & 1993 & 2002 \\
Spring Chinook H & 1993 & 2002 \\
Summer Chinook H & 1994 & 2002 \\
Summer Chinook W & 1994 & 2002 \\
Summer Steelhead H & 1994 & 2002 \\
Summer Steelhead W & 1994 & 2002 \\
Spring Chinook H & 1995 & 2000 \\
Spring Chinook W & 1993 & 2002 \\
Summer Steelhead W & 1993 & 2002 \\
Summer Sockeye H & 1998 & 2000 \\
Summer Sockeye W & 1994 & 1995 \\
Unknown Chinook H & 1993 & 1995 \\
Unknown Chinook W & 1993 & 2002 \\
Summer Steelhead H & 1993 & 1995 \\
Summer Steelhead W & 1993 & 1995 \\
\hline
\end{tabular}


The PIT-tag analyses include reach survival and travel time estimates that can be accessed interactively at http://www.cbr.washington.edu/pitSurv/. Each year, as in 2003, the status and trends of the smolt survival and travel time estimates are updated. Figure 3 illustrates the type of data plots available on the DART system. An important additional set of information is the historical capture probabilities at the various PIT-tag detection facilities. These capture probabilities are useful in the design of future PIT-tag release-recapture studies.

\subsection{Adult Escapement Trends}

NOAA Fisheries has come out with target escapement goals for adult returns for 32 tributary systems and 70 salmonid stocks in the Pacific Northwest (Cassidy, 4 April 2002, Interim Abundance and Productivity Targets). These escapement goals are part of the adult performance measures associated with recovery. Unfortunately, the escapement data, based on redd counts and adult counts, used by NOAA Fisheries were not specified in the 4 April 2002 memo. Some or all of the adult escapement data compiled by StreamNet were used in the NOAA deliberations. During this last year, interaction with StreamNet and NOAA Fisheries staff (e.g., Tom Cooney) has been successfully undertaken to determine what escapement data correspond with the NOAA target goals. The geographic database will present a map of stream locations (Figure 4) and resulting associated plots (Figure 5). The following streams and stocks now have integrated escapement trend data and interim escapement goals:

\section{Spring/Summer Chinook Salmon}

Spawning Aggregations

Upper Columbia:

Methow

Entiat

Wenatchee

Snake River:

Tucannon

Grande Ronde

Imnaha

South Fork Salmon

Middle Fork Salmon

Lemhi

Pahsimeroi 
Figure 3. Illustrations of historical trends in survivals and travel times from Winthrop Hatchery to McNary Dam for spring chinook salmon smolts, 1993-2003.
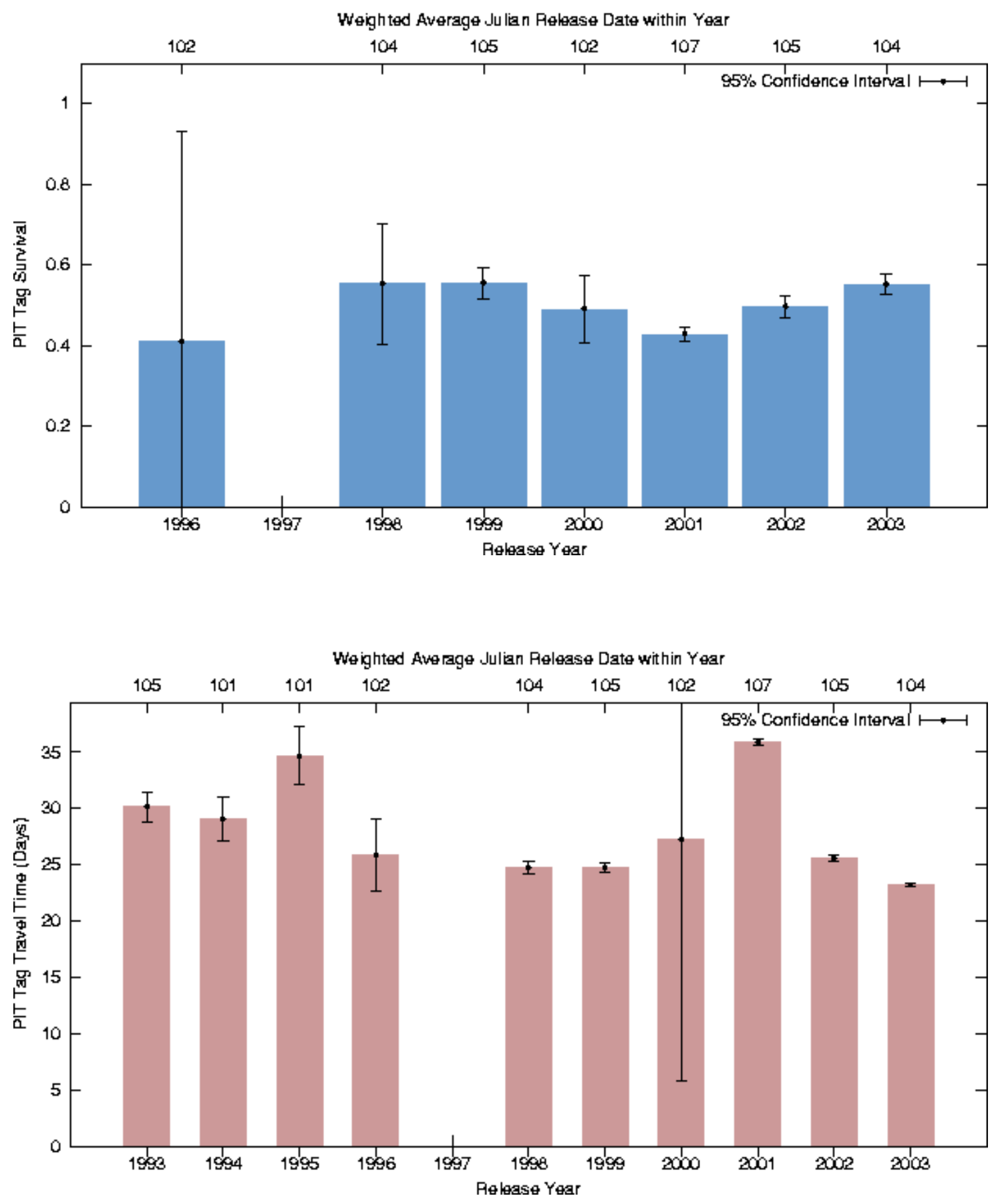
Figure 4. Map of NOAA Fisheries streams and index areas with interim adult escapement goals.

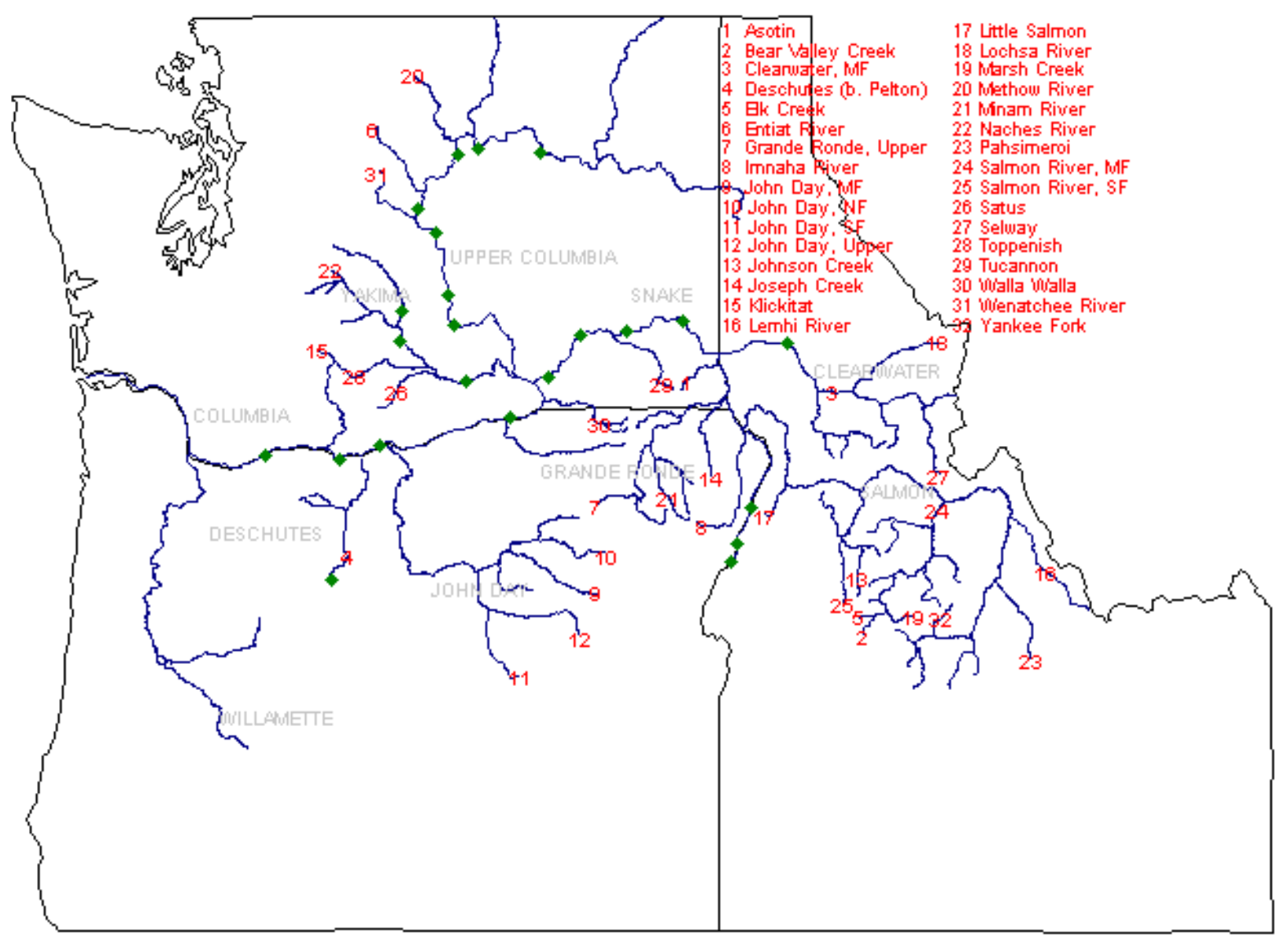


Figure 5. Examples of NOAA Fisheries interim escapement goals compiled with the appropriate StreamNet adult escapement data for (a) spring/summer chinook salmon in the Methow Subbasin, (b) spring/summer chinook salmon in the Wenatchee subbasin.

a.

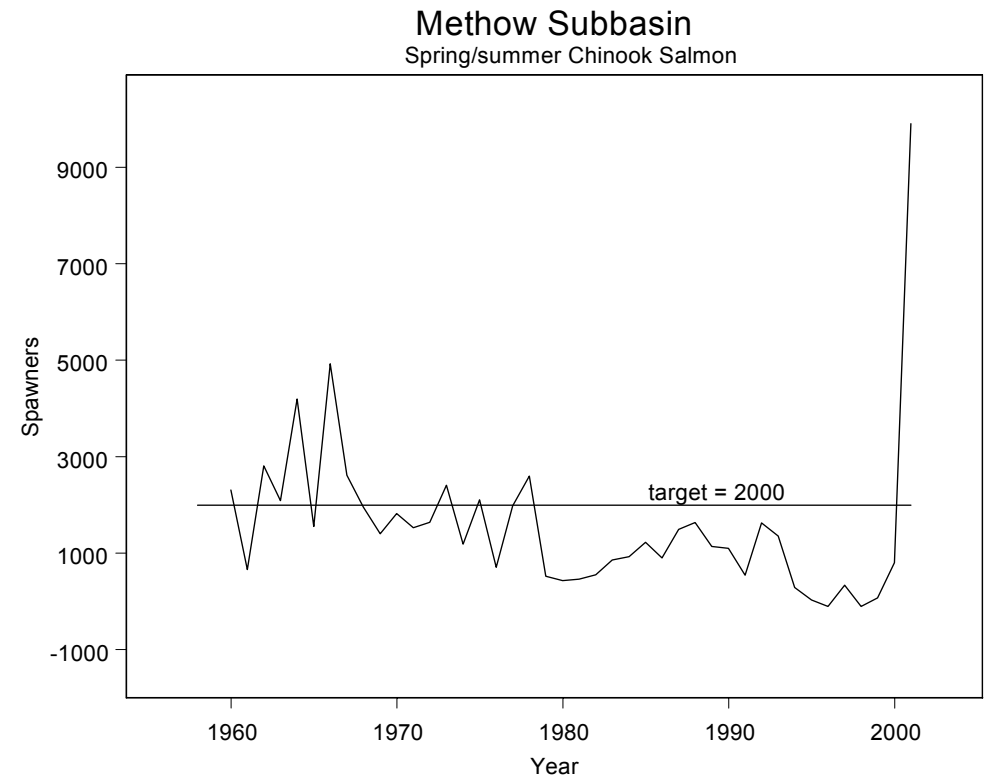

b.

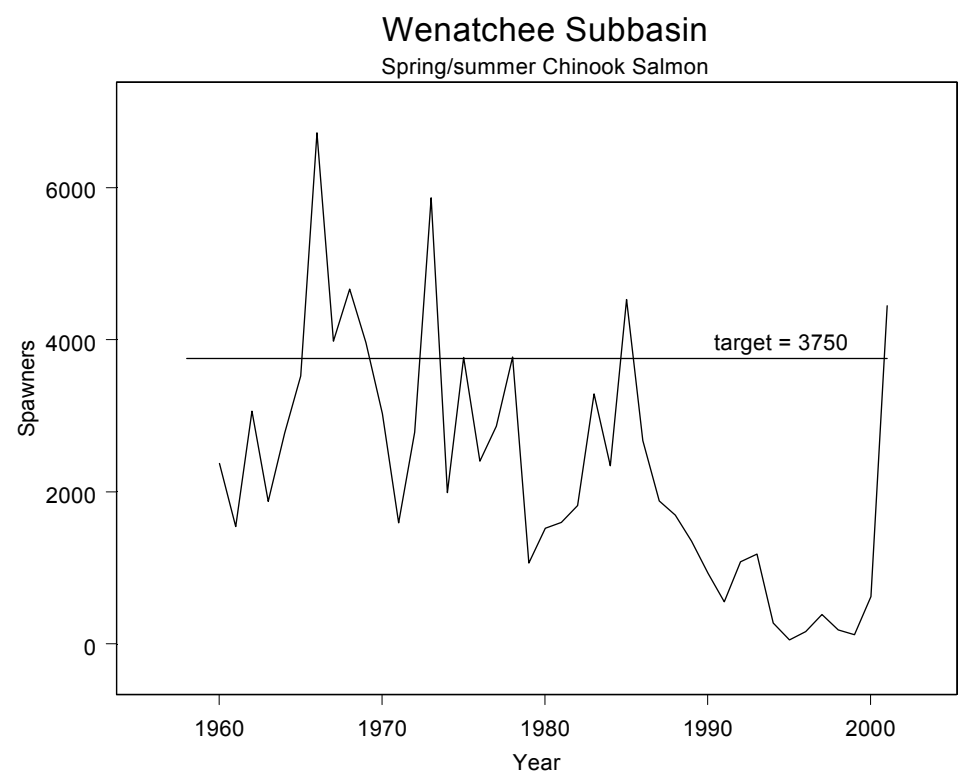


Upper Salmon River

Lemhi

Yankee Fork

Index Areas

Snake River:

Minam River (tributary to the Grande Ronde)

Mainstem Imnaha River

Johnson Creek (tributary to the South Fork Salmon)

Bear Valley/Elk Creek

Marsh Creek (tributaries to the Middle Fork Salmon River)

\section{Fall Chinook Salmon}

Spawning Aggregation from the Snake River

\section{Sockeye Salmon}

Spawning Aggregation from the Snake River

\section{Steelhead Trout}

Spawning Aggregations

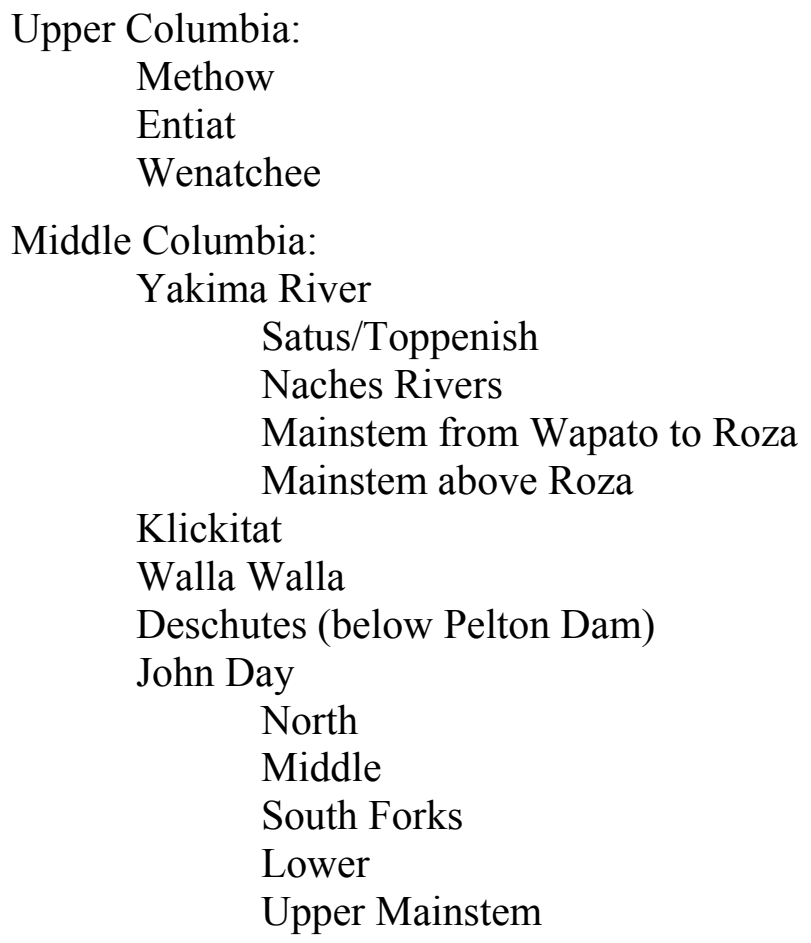




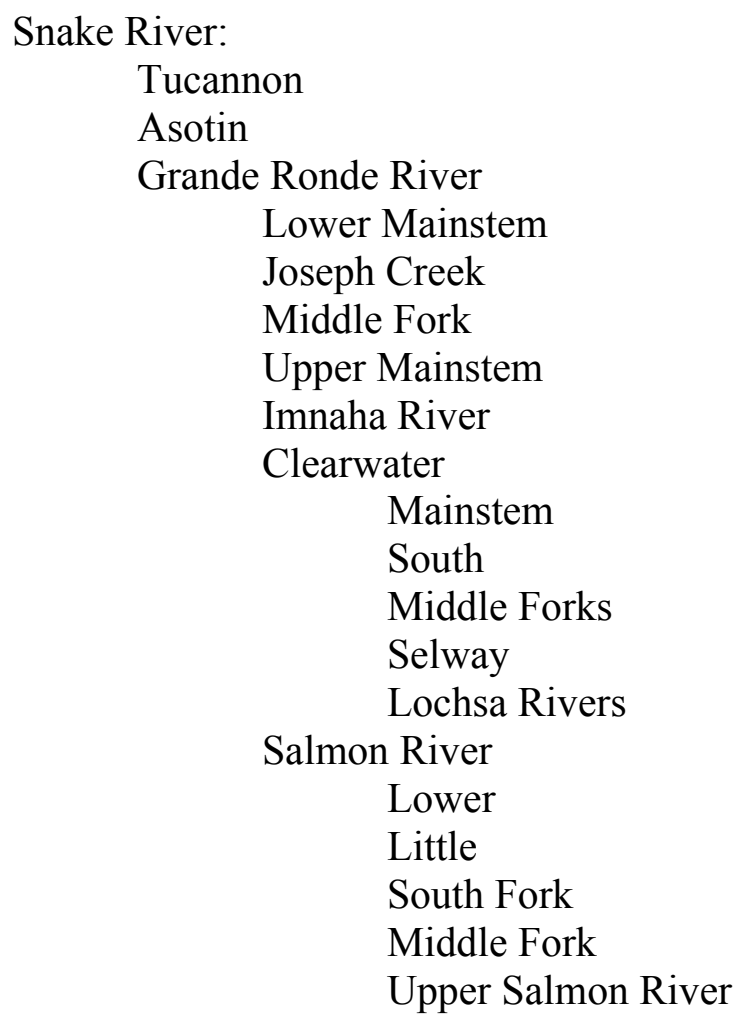

\subsection{Evaluation of Performance Standards}

Working with RM\&E Hydro Working Group and NOAA Fisheries, statistical decision rules for assessing recovery were evaluated as well as constructed under this task in 2003. Using Monte Carlo simulation techniques, the statistical power of decision rules to correctly identify recovery were evaluated. The first rules evaluated were the proposed statistical tests specified in the BiOp. However, those rules were found to have a very low probability of correctly identifying smolt survivals at or above BiOp requirements (Table 1).

Instead, multivariate decision criteria were found to be much more powerful at detecting recovery compliance (Table 1). The multivariate decision rule was based on the statistical significance (i.e., P-value) of three separate tests; these are: 
Table 1. Statistical power $(1-\beta)$ to conclude compliance in 2010 for yearling chinook salmon survival from Lower Granite to Bonneville at $\alpha=0.05$ under various recovery scenarios.

\begin{tabular}{cccc}
\hline Scenario & & Original BiOp Test & Multiple Test Criteria \\
\hline Recovery by year & 2010 & 0.200 & 0.655 \\
& 2009 & 0.220 & 0.715 \\
& 2008 & 0.268 & 0.766 \\
& 2007 & 0.331 & 0.805 \\
& 2006 & 0.387 & 0.834 \\
2005 & 0.434 & 0.851 \\
2004 & 0.504 & 0.858 \\
& 2003 & 0.601 & 0.855 \\
2002 & 0.605 & 0.841 \\
2001 & 0.738 & 0.810 \\
\hline
\end{tabular}


1. $\mathrm{H}_{\mathrm{o}}: \quad \beta \leq 0$

$\mathrm{H}_{\mathrm{a}}: \quad \beta>0$

where $\beta$ is the slope of regression trend over time.

2. $\mathrm{H}_{\mathrm{o}}: \quad \mu_{\text {Post }} \leq \mu_{\text {Pre }}$

$\mathrm{H}_{\mathrm{a}}: \mu_{\text {Post }}>\mu_{\text {Pre }}$

where $\mu$ is the mean response either pre- or post-2000.

3. $\mathrm{H}_{\mathrm{o}}: \quad \gamma \leq \mu_{\mathrm{Pre}}$

$\mathrm{H}_{\mathrm{a}}: \gamma>\mu_{\mathrm{Pre}}$

where $\gamma$ is the asymptote of a hyperbolic curve on post-2000 data.

The decision rule assesses significance based on the pattern of results of the three separate tests. The multivariate decision rules were found to have an increase in statistical power of 0.072 to 0.455 over that of the BiOP proposed tests. This translates to as much as a three-fold increase in the likelihood of concluding recovery if it indeed occurs.

\subsection{Technical Reports}

The following technical reports have been completed and made available to the fisheries community during the last year as a consequence of this BPA project and its technology transfer.

\section{$\underline{\text { Reports }}$}

1. Burgess, C., and J. R. Skalski. 2003. Evaluation of the 2003 predictions of the runtiming of wild and hatchery-reared salmon and steelhead smolt to Lower Granite, Rock Island, McNary, and John Day dams using Program RealTime. Monitoring and evaluation of smolt migration in the Columbia Basin, Volume XI. Bonneville Power Administration, Portland, OR.

2. Burgess, C., T. J. Miller, and J. R. Skalski. 2003. Precision and accuracy of the transportation-to-inriver (T/I) ratio estimator of survival benefits to juvenile salmonids transported around the Columbia River Basin dams. The design and analysis of salmonid 
tagging studies in the Columbia Basin, Volume XVIII. Bonneville Power Administration, Portland, OR.

3. Carlson, T. H., P. L. Marston, G. Keilman, J. R. Skalski, and L. H. Sheldon. 2003. Review of the application of an acoustic scintillation flow meter for hydroturbine discharge estimation. Prepared for U.S. Army Corps of Engineers, Northwest Division, Contact DACW57-00-D-0009-0006. Battelle, Pacific Northwest Division, Richland, WA. PNWD-3217.

4. Johnson, G. E., M. E. Hanks, J. B. Hedgepeth, B. D. McFadden, R. A. Moursund, R. P. Mueller, and J. R. Skalski. 2003. Hydroacoustic evaluation of turbine intake Jocclusions at The Dalles Dam in 2002. Final report for the U.S. Army Corps of Engineers, Portland District, under Contract DACW57-00-D-009. Battelle Memorial Institute, Pacific Northwest Division, Richland, WA.

5. Skalski, J. R. 2003. Hypothetical examples of survival trends and compliance assessment. Prepared for the RME-Hydro Working Group, Portland, OR.

\section{$\underline{\text { Technology Transfer and Collaboration }}$}

1. Skalski, J. R. 2003. Statistical analysis plan for the 2003 acoustic-tag FPE studies at Rocky Reach and Rock Island dams. Prepared for PUD No. 1 of Chelan County, Wenatchee, WA.

2. Stevenson, J. R., J. R. Skalski, P. Westhagen, and A. E. Giorgi. 2003. Telemetry investigation: Fish passage efficiency of juvenile yearling and subyearling chinook, steelhead and sockeye at Rocky Reach and Rock Island dams, 2003. Prepared for PUD No. 1 of Chelan County, Wenatchee, WA. 


\subsection{Summary of Technology Transfer Efforts}

Each year, research staff of this project are asked to assist fisheries investigators in the design and interpretation of monitoring and evaluation studies. These efforts are used to help elevate the precision and cost-effectiveness of studies supported by the Fish and Wildlife Program. Support is provided to federal and state agencies, tribes, and public utility districts dealing with smolt and adult salmonid tagging studies. These efforts are summarized, in part, by the joint authorship of technical reports and papers listed in Section 3.0. Other efforts are characterized by attending technical support meetings in the community, direct person-to-person assistance, and collaboration on monitoring and evaluation studies.

The technical support is of two categories of effort. Direct effort supported by funds of this project. Typically, these efforts are focused at assisting BPA and other action agencies in designing better monitoring and evaluation studies and program. Example of activities during 2003 include the following:

1. Assisting the RME-Hydro Group with statistical decision criteria for assessing compliance with recovery criteria for smolt survival through the hydrosystem.

2. Assisting USACE with evaluating alternatives for conducting a McNary turbine survival study to assess the effects of alternative operating levels on smolt passage survival. Evaluations compared the costs of conducting radiotelemetry versus PIT-tag releaserecapture methods. The evaluation may result in $\$ 8-9 \mathrm{M}$ in study cost-savings.

3. Assisting the Northwest Power and Conservation Council, USACE, USGS, and NOAA Fisheries in evaluating alternative summer spill study proposals for 2004.

The second type of support is indirect support where funds are not directly used to support consulting efforts. Rather, technical support exists because of the capabilities and long-term staffing made available by BPA ongoing funding. In these circumstances, agencies and investigators avail themselves of UW Columbia Basin Research assistance by funding such efforts themselves. Nevertheless, such assistance and technological expertise would not exist if 